\title{
Unwelcome Guests: The Detention of Refugees in Turkey's "Foreigners' Guesthouses"
}

\author{
Rachel Levitan, Esra Kaytaz, and Oktay Durukan
}

\begin{abstract}
As European countries bordering the Mediterranean have introduced increasingly harsh measures to stem the flow of irregular migration across their frontiers, Turkey has become one of the main crossroads for flows of migration from Africa, Asia, and the Middle East into Europe. At the same time, as part of Turkey's accession process, the European Union has stepped up pressure on Turkey to prevent the movement of migrants, asylum seekers, and refugees into Europe. As a result of Turkey's efforts to limit irregular migration flows, thousands of foreign nationals without travel documents, refugees among them, are detained while attempting to either enter or exit the country illegally. They are primarily held in detention centres, which are officially referred to as "foreigners' guesthouses." Turkey's Ministry of Interior (MOI) severely limits access to detainees in these facilities by international and domestic NGOs and advocates. Helsinki Citizens' Assembly Turkey (HCA), a leading human rights NGO based in Istanbul, has provided legal aid to refugees since 2004 through its Refugee Advocacy and Support Program. Based on interviews conducted by HCA with forty refugees from seventeen countries, this report examines refugees' access to procedural rights in detention, as well as conditions in "foreigners' guesthouses." It identifies gaps between reported practice and standards of treatment set forth in Turkish legislation and international guidelines on detention.
\end{abstract}

\section{Résumé}

Alors que les pays européens riverains de la Méditerranée mettent en place des mesures de plus en plus sévères pour endiguer les flux de la migration irrégulière à travers leurs frontières, la Turquie devient l'un des principaux carrefours des flux migratoires vers l'Europe en provenance
d'Afrique, d'Asie et du Moyen-Orient. Dans un même temps, dans le cadre du processus d'adhésion de la Turquie à l'Union européenne, cette dernière a intensifié la pression sur les autorités turques pour empêcher la circulation de migrants, demandeurs d'asile et réfugiés vers l'Europe. Suite aux efforts de la Turquie à limiter les flux migratoires irréguliers, des milliers de ressortissants étrangers sans papiers, réfugiés parmi eux, sont détenus soit en tentant de pénétrer ou de quitter le pays illégalement. Ils sont pour la majorité placés dans des centres de détention, officiellement désignés "centre d'hébergement pour étrangers ». Le ministère de l'Intérieur turc limite sévèrement l'accès des ONG nationales et internationales et des défenseurs des réfugiés aux détenus dans ces établissements. La Helsinki Citizens' Assembly - Turkey (HCA), chef de file des ONG des droits humains basée à Istanbul, fournit une aide juridique aux réfugiés depuis 2004 grâce à son programme de défense et de soutien des réfugiés. Appuyé par des entretiens qu'a menés la HCA avec une quarantaine de réfugiés provenant de dix-sept pays, cet article étudie le droit procédural des réfugiés en détention, ainsi que les conditions dans les "centres d'hébergement. " L'auteur identifie des lacunes entre les pratiques déclarées et les normes de traitement énoncées à la fois dans le droit turc et les directives internationales sur la détention.

\section{Introduction: The Report and Its Impact}

This report, originally released by Helsinki Citizens' Assembly Turkey (HCA) in April 2008, was the first published evaluation of the conditions and practices in Turkey's migrant detention centres, known as "foreigners' guesthouses." For a number of years, HCA had been receiving requests for legal assistance from individuals held in these facilities. Many complained of difficulties applying for 
asylum, not understanding why they were detained or when they would be released, and of unhealthy detention conditions. HCA chose to compile the data gathered from these detainees and conduct a series of detailed interviews in order to get a more complete picture of the detention of migrants and refugees in Turkey. Since Turkey's Ministry of Interior (MOI) denied HCA access to the facilities-and still doesthe respondents were interviewed either over the phone, or in person, after they had been released. The resulting report was conceived as an advocacy tool to raise public awareness both domestically and internationally about the protection gaps in Turkey's "foreigners' guesthouses."

Before the report's publication, and as a means of supporting dialogue with the Turkish government, HCA sent it to MOI for comments. Almost three months later, MOI provided an "informal" email response to the report, essentially repudiating its methodology and findings. MOI's central objection was that since the facilities in question did not house "refugees," but "illegal migrants," the report's findings regarding the treatment of refugees were inaccurate. MOI also questioned the reliability of the anonymous testimony on which the report's findings were based. HCA published a summary of MOI's arguments as well as a detailed response along with the report.

In its reply to the government, HCA noted that the report's use of the term "refugee" is consistent with international norms, and includes all individuals who express a fear of persecution and intend to apply for, have applied for, or have been granted "refugee status." HCA also countered that the broad use of the term "illegal migrant" fails to take account of the fact that many refugees fleeing persecution travel without proper documentation. Moreover, HCA argued, domestic and international detention standards apply to all detainees regardless of their legal status. In response to MOI's objections regarding the reliability of the testimony used in the report, HCA noted that stringent ethical criteria were applied when carrying out the interviews and that the use of anonymous quotes in acknowledgement of the respondents' confidentiality concerns was entirely consistent with established practices of other human rights reporting organizations.

MOI's reaction to the publication of the report was initially very negative. It cut off all communication with HCA by, among other things, refusing to allow local Foreigners' Police officials to attend capacity building seminars held by HCA for local NGOs and government officials. It also refused to invite HCA to a series of government-NGO consultations regarding the development of EU-funded refugee "reception centres." Significantly, MOI also placed further limitations on UNHCR's access to refugees in detention. In departure from previous practice, MOI denied UNHCR's access to detainees whose requests for asylum had not already been processed by MOI authorities in Ankara. This limitation, which remains in effect, is exacerbated by the fact that local Foreigners' Police regularly refuse to accept asylum applications from anyone who did not apply for asylum before being detained. In some cases, the limitation on UNHCR's access has also provided MOI with a window of time to deport detainees before they are able to access asylum procedures.

But almost a year after its publication, the positive impact of the report is beginning to come to light. It has given HCA an important platform from which to continue to advocate for the rights of detainees in "foreigners' guesthouses" and raise awareness about barriers to domestic asylum procedures. Following a series of riots at guesthouses in Istanbul, Kirklareli, and Edirne (cities near the Turkish-Greek border) domestic media sought commentary from HCA on the detention of migrants in Turkey and some of the media coverage specifically referred to HCA's report. The publication of the report has also led to several meetings between HCA and European delegations to Turkey investigating the treatment of migrants and refugees. HCA has also been invited to discuss the conditions and legality of Turkey's migrant detention places at several international meetings, including at hearings in the European Parliament.

Government bodies in Turkey have also taken important steps to address issues raised in HCA's report. A parliamentary human rights commission has taken a strong interest in investigating the conditions in "foreigners' guesthouses." Similarly, provincial human rights boards in Istanbul and Edirne have taken pragmatic steps to improve facility conditions.

Despite these positive steps, much work needs to be done to improve migrant detainees' access to asylum procedures and detention conditions. MOI continues to engage in acts of refoulement ${ }^{1}$ and detain refugees for indefinite periods in "foreigners' guesthouses." Individuals apprehended in airport "transit zones" are still prohibited from making asylum claims and barred from accessing the UNHCR, NGOs, or legal assistance providers. Detention conditions in most "foreigners' guesthouses" are still well below standard and those detained continue to have difficulty applying for asylum and accessing legal assistance.

Building on the positive impact of the report, HCA has expanded its assistance to refugees in detention and those facing deportation. In the months following the publication of the report, HCA secured a breakthrough decision from a Turkish administrative court which held that indefinite detention in a "foreigners' guesthouse" violated domestic law. Over the course of 2008, HCA has also successfully used the urgent "interim measure" procedure of

(C) Rachel Levitan, Esra Kaytaz and Oktay Durukan, 2009. This open-access work is licensed under a Creative Commons AttributionNonCommercial 4.0 International License, which permits use, reproduction and distribution in any medium for non-commercial purposes, provided the original author(s) are credited and the original publication in Refuge: Canada's Journal on Refugees is cited. 
the European Court of Human Rights (ECtHR) ${ }^{2}$ to prevent numerous illegal deportations of refugees. HCA is pursuing two cases in the ECtHR challenging Turkey's refusal to accept or examine asylum applications in airport "transit zones."

\section{Methodology}

In the absence of other research regarding the detention of refugees in Turkey, HCA conducted interviews with forty refugees from seventeen countries who either were in detention at the time of the interviews or had been in detention before. The interviewees are not representative demographically of the population of refugees and asylum seekers in Turkey. In terms of their asylum status, they either were already in process within the asylum procedure or expressed their intentions to apply for asylum while in detention. The report uses the data from these interviews, as well as information received from detainees during the course of telephone counselling sessions with HCA legal advisors.

Interviewees were given a standard questionnaire relating to the conditions of their arrest and detention. The questionnaire is divided into nine subsections: basic information, physical conditions in detention, information provided in detention, interactions with the police, health care, visits, differential treatment of detainees, asylum applications and social relations among detainees. These categories of analysis reflect minimum standards of protection for refugees in detention set out both in the 1999 UNHCR Revised Guidelines on Applicable Criteria and Standards relating to the Detention of Asylum-Seekers (UNHCR Detention Guidelines) and the 2003 European Council Directive laying down minimum standards for the reception of asylum seekers. In this way, the information collected by the questionnaires facilitates an analysis of the degree to which the Turkish authorities are complying with international standards on detention practices.

Interviewees came from diverse countries and were primarily male. The largest number of interviewees came from the Democratic Republic of Congo, followed by Ethiopia and Ivory Coast. Other countries of origin included Afghanistan, Burundi, Eritrea, Guinea Bissau, Iran, Iraq, Liberia, Mauritania, Nigeria, Palestinian Territories, Philippines, Somalia, Sudan, and Uganda.

Interviewees provided information about each separate instance they were detained (with the exception of one man who gave information only about two of his ten arrests). In total, forty-six instances of detention were recorded, since five of the detainees were arrested more than once. The questionnaires were filled out in 2006 and 2007 and cover incidences of detention that go back to the year 2004. Thirteen interviews involved arrests in 2007; twenty-five in 2006; five in 2005; and three in 2004.

In total, guesthouses and other detention facilities in seven cities were surveyed. Most interviewees discussed their experiences in facilities in Istanbul (twenty-seven), followed by Kirklareli (seven), Edirne (four), Izmir (four), Ankara (two), Hatay (one), and Van (one).

The majority of the respondents were held in Istanbul. This bias is largely based on the fact that HCA is located in Istanbul. Interviewees provided information about all three of the Istanbul guesthouses. The guesthouse located in Istanbul Security Directorate buildings on Vatan Avenue was open until the spring of 2006, when the guesthouse was moved to the Zeytinburnu Security Directorate. In March 2007, a new guesthouse was opened in the Kumkap1 district of Istanbul. In addition to facilities in Istanbul, the report also surveys guesthouses in Izmir, Ankara, Van, Hatay, both guesthouses in Edirne (the Tunca Camp and the guesthouse in the centre of the city) and the Kirklareli guesthouse. Interviewees also provided information about detention facilities other than guesthouses, such as police stations in Istanbul, gendarmerie posts in Izmir and Van, and minors' detention facilities in Istanbul, as well as the transit zone in the Istanbul Ataturk Airport.

The interviews were conducted in consideration of the ethics of interviewing vulnerable individuals. The interviewees were guaranteed full anonymity. Any information that would render individual interviewees identifiable has been removed from the report. Every effort was made to ensure that the interviews were conducted in a manner that did not cause the interviewees additional stress. Interviewees were also compensated for travel costs.

\section{Legal Context for the Protection of Refugees in Turkey}

Although one of the original signatories to the 1951 Refugee Convention and the 1967 Protocol, Turkey adopted the 1951 Convention relating to the Status of Refugees (Refugee Convention) with the so-called "geographical limitation" clause. ${ }^{3}$ That clause provided State Parties the option of restricting their 1951 protection obligations to individuals who became refugees "as a result of events occurring in Europe." To date, Turkey remains one of the few State Parties to the Refugee Convention to retain the geographical limitation and considers itself bound by its 1951 obligations only with respect to nationals of so-called "European countries of origin." ${ }^{4}$

Notwithstanding this legal limitation, in reality, the current profile of people seeking international protection in Turkey almost exclusively consists of individuals originating from "non-European" countries-most significantly 
Iraq, Iran, Afghanistan, Somalia, Sudan, and other states in Africa and Asia. ${ }^{5}$ For these non-Europeans, Turkey assumes a limited responsibility, offering the prospect of what is termed "temporary asylum." Turkey's temporary asylum regime for non-European refugee applicants involves parallel procedures, one administered by the Turkish MOI and the other by UNHCR Branch Office Ankara (which operates under a Memorandum of Understanding with the Turkish government).

Non-European refugee claimants in Turkey are required to file two separate applications, one with the UNHCR and one with the MOI. The UNHCR conducts refugee status determination (RSD) to adjudicate individual refugee claims. Those who are found to meet the definition of a refugee as defined by the Refugee Convention are "recognized" as such and subsequently resettled in a third country. The main resettlement countries for Turkey are the US, Canada, and Australia.

Alongside the UNHCR procedure, refugee claimants are required to file a separate "temporary asylum" application with the Turkish government. The purpose of the government procedure is to determine-independently from the UNHCR assessment-whether the applicant has a legitimate need for temporary asylum in Turkey as specified by Turkey's national legislation. The government department in charge of administering Turkey's temporary asylum regime is the Foreigners' Borders and Asylum Division of the General Directorate of Security under the MOI. Turkey understands temporary asylum for non-Europeans as a unilateral commitment that does not directly flow from its core obligations under the Refugee Convention beyond a general undertaking to "cooperate with UNHCR ... in the exercise of its functions." 6

The backbone of Turkey's asylum legislation, the 1994 Asylum Regulation, was enacted in November 1994 and subsequently amended in 1999 and 2006. It essentially replicates the refugee definition set forth in the Refugee Convention in establishing who can benefit from temporary asylum protection. ${ }^{7}$ However it allows significant room for administrative discretion in the processing of applications for temporary asylum. It was not until June 2006 that the Turkish government formally defined the procedure in a circular (2006 Circular) outlining the specific rights, benefits, and obligations of temporary asylum applicants. Other legislation that informs the asylum procedure includes the Passport Law (No. 5683), the Law on Sojourn and Movement of Aliens (No. 5687), the Law on Settlement (No. 2050), and the Citizenship Law (No. 5682).

The main feature of Turkey's temporary asylum system is a policy of dispersal. Under MOI and UNHCR coordination, temporary asylum claimants are referred to one of twenty- eight so-called "satellite cities"- -the term informally used to describe the provinces designated by the MOI where asylum seekers are required to reside. ${ }^{8}$ These satellite cities are mostly located in interior regions of the country. Refugee applicants are required to pursue their temporary asylum applications with the "Foreigners' Police" in the province to which they are assigned and must reside there until the final determination on their applications are made. According to the 1994 Regulation, asylum seekers who arrived in Turkey legally must register with the police in the city where they currently reside, while those who entered illegally must register in the province they first entered in Turkey.

There is no specific time limit to register, but refugee applicants are expected to approach the authorities "without delay." Those who fail to apply "within the shortest time span possible" are obliged to explain their reasons for the delay and must co-operate with competent authorities. ${ }^{9}$ The 2006 Circular, however, expressly stipulates that even where an applicant "failed to apply within a reasonable time period" and "cannot provide any reasonable excuse," asylum authorities are required to accept their applications "without prejudice." 10

Typically, refugee applicants first approach the UNHCR. Following their registration, they are informed by the UNHCR of the province to which they must report in order to file their "temporary asylum" application with the Turkish government. Refugee applicants generally have no input on the province to which they will be assigned, but they may be assigned to live in a province where family members reside. Once registered as "temporary asylum applicants," they are required to regularly report to local police to document their continued residence in the city. Refugee applicants may apply to local police authorities to receive written permission to temporarily leave their assigned province. Leaving one's assigned city without permission may result in criminal charges.

Refugee applicants must pay a "residence" fee for each family member every six months, which is often prohibitively high. Once this is paid, a residence permit is issued, which usually is a prerequisite to the receipt of medical care and education. Refugee applicants are almost always required to cover the cost of their accommodation and health care. Although refugee applicants have been granted a nominal right to employment, this right is rarely exercised due to legal barriers associated with receiving work permits, language barriers and strains on the labour market.

UNHCR offers very modest financial assistance to "recognized" refugees and "one-time special" assistance to vulnerable refugee applicants in emergency situations. Under the 2006 Circular regime, the Turkish government does not undertake any commitment to assist refugee applicants in

(C) Rachel Levitan, Esra Kaytaz and Oktay Durukan, 2009. This open-access work is licensed under a Creative Commons AttributionNonCommercial 4.0 International License, which permits use, reproduction and distribution in any medium for non-commercial purposes, provided the original author(s) are credited and the original publication in Refuge: Canada's Journal on Refugees is cited. 
need of shelter, health care, and subsistence assistance other than a non-binding reference to the role of Social Solidarity and Assistance Foundations organized under provincial governorates. These government agencies are mandated to attend to the social assistance needs of "all residents of the province" including, by definition, refugees. ${ }^{11}$ In practice, however, the support provided by these agencies to refugees in satellite cities is far from adequate.

The direction of Turkish asylum policy is largely influenced by Turkey's agenda for EU accession. Turkey is expected to adopt the EU acquis in the area of asylum and migration in accordance with the Accession Partnership Strategy of March 2003 and the National Program for the Adoption of the EU Acquis of July 2004. In January 2005, the Turkish government adopted a "National Action Plan for Asylum and Migration" (NAP) and pledged to undertake a series of measures to align asylum policy and practice with EU standards, including administrative and technical capacity development, training of specialized staff, and changes in legislation. On the critical issue of lifting the "geographical limitation," the NAP stipulates that "a proposal for lifting the geographical limitation may be expected to be submitted to the Parliament in 2012 in line with the completion of Turkey's negotiations for accession," and on the condition that necessary changes in legislation and infrastructure have been completed to "prevent the direct influx of refugees to Turkey during the accession phase" and "EU Member States' demonstrated sensitivity in burden sharing." 12

\section{Legal Framework for the Detention of Refugees in Turkey \\ What Is a "Foreigners' Guesthouse"?}

Foreign nationals are detained in Turkey for a variety of reasons, whether as a result of alleged criminal activity, illegal entry or exit from the country, or failure to comply with requirements of the temporary asylum system. After the conclusion of criminal court procedures relating to these charges, foreign nationals are denied their freedom of movement. The justification for their detention is that it is the most effective means of carrying out relevant administrative procedures, such as deportation or assignment and transfer to a satellite city. Foreign nationals are detained without a court order; they are held based only on an administrative ruling from the Ministry of Interior. Detainees are never informed and are rarely aware that they are no longer being held pursuant to a judicial process but according to administrative regulations. This is exacerbated by the fact that they generally are in contact with the same police personnel during their stay in detention.

Most detainees are held in "foreigners' guesthouses," though a minority are detained in police stations and airport transit zones. Despite the name, these "guesthouses" are effectively detention centres in which detainees are held involuntarily. Detention facilities have been defined as "custodial settings ranging from holding facilities at points of entry, to police stations, prisons and specialized detention centers." 13 Although guesthouses in Turkey are not officially referred to as "detention facilities," they clearly fall within this definition. ${ }^{14}$

A proportion of foreign nationals detained in guesthouses are refugees. In the refugee context, UNHCR has defined detention as "confinement within a narrowly bounded or restricted location, including prisons, closed camps, detention facilities or airport transit zones, where the only opportunity to leave this limited area is to leave the territory." 15 Refugees, like other foreign nationals detained in guesthouses, are not allowed to leave freely, and as such, are under detention. Guesthouses should be distinguished from "accommodation centers," which are locations used only "for collective housing of applicants for asylum and their accompanying family members." 16

In Turkey, guesthouses are administered by the Tracing and Control Police Section of the Foreigners' Department of each City Security Directorate. The Tracing and Control Police are responsible for foreign nationals who have entered or attempted to exit Turkey illegally, are found in violation of visa regulations, or have allegedly committed illegal activities. ${ }^{17}$

The rights of detainees, including refugees, are derived from the substantial curtailment of their freedom of movement-regardless of the justification given for the detention (i.e., whether for criminal or administrative purposes). Despite this, states commonly abrogate their legal obligations to refugees in detention, who may be confined for indefinite lengths of time in substandard conditions, with limited or no recourse to judicial review. ${ }^{18}$ Refugees in Turkey face similar experiences in detention. While there are explicit safeguards for criminal detainees in Turkey, there are few such safeguards for those in administrative detention, and no explicit standards relating to the detention of foreign nationals. ${ }^{19}$

This section lays out domestic and international standards relating to the procedural rights of detained foreign nationals, including refugees, and the minimum standards for detention conditions.

\section{Procedural Rights and Practice}

\section{Grounds for the detention of refugees}

Domestic law. The provisions of Turkish law most relevant to the apprehension and detention of refugees relate to irregular movement. In particular, domestic law provides that

(C) Rachel Levitan, Esra Kaytaz and Oktay Durukan, 2009. This open-access work is licensed under a Creative Commons AttributionNonCommercial 4.0 International License, which permits use, reproduction and distribution in any medium for non-commercial purposes, provided the original author(s) are credited and the original publication in Refuge: Canada's Journal on Refugees is cited. 
foreign nationals in violation of their residence status may be detained, and criminally charged, for the following violations: illegal entry, ${ }^{20}$ illegal exit, ${ }^{21}$ and leaving the designated city of residence without permission. ${ }^{22}$

Refugees, like other foreign nationals apprehended by police in Turkey with irregular status, are generally detained in guesthouses. Upon being detained, they are usually charged with a criminal violation (i.e., for illegal entry or exit and residence violations). However, typically, for the majority of their time in detention, refugees are held for administrative purposes, including: to have their asylum application processed, to be assigned a satellite city, or to be processed for deportation.

No domestic law provides a legal basis for the detention of foreign nationals in guesthouses. Article 23 of the Law on Residence of Foreign Citizens is relevant in that it provides that foreigners who have been issued a deportation order but cannot be immediately expelled "shall reside in a location assigned to them by the Ministry of Interior." ${ }^{23}$ However, neither that provision nor any other in domestic law provides a framework for the duration or conditions of detention in guesthouses. ${ }^{24}$

International law and guidelines. Liberty is a fundamental human right. Multiple international instruments, including the Universal Declaration of Human Rights (UDHR), the International Covenant on Civil and Political Rights (ICCPR), and the European Convention on Human Rights provide that no one should be arbitrarily deprived of his or her liberty. Refugees, clearly, are also entitled to this right.

However, since many refugees are forced to enter a country illegally to escape persecution, they may find themselves in violation of local law in their country of asylum. As a result, Article 31 of the Refugee Convention prohibits the punishment of refugees for illegal entry if they present themselves to authorities and show good cause for their illegal entry or presence.

International law and standards also specify that, as a rule, refugees should not be detained. ${ }^{25}$ If they are, the detention "should not be automatic [or] unduly prolonged" 26 and must only take place for these exceptional reasons: ${ }^{27}$

- to verify identity;

- to determine the elements on which the claim for refugee status or asylum is based;

- in cases where refugees have destroyed their travel and/or identity documents or have used fraudulent documents in order to mislead the authorities of the state in which they intend to claim asylum; or

- to protect national security and public order.

\section{The right to access asylum procedures}

Consistent with rights enshrined in the Refugee Convention, Turkish legislation recognizes the right of foreign nationals who enter Turkey illegally to apply for asylum. ${ }^{28}$ The law provides that asylum applications will not be prejudiced so as long as the applicant approaches the police for registration in the shortest time possible after entering the country and can account for any delay. ${ }^{29}$

The UNHCR Detention Guidelines specifically state that "detention should not constitute an obstacle to asylum seekers' possibilities to pursue their asylum application." 30

However, as discussed earlier, foreign nationals detained in guesthouses are often denied the right to apply for asylum in detention, whether because they are not informed of the asylum procedure, have no access to an interpreter, or are prohibited from submitting an asylum application. Of particular concern is the fact that those held in transit zones in Turkish airports are flatly prohibited from applying for asylum, as discussed below under "Airport Transit Zones."

A troubling outcome of the denial of access to asylum procedures is the risk of refoulement-that is, return to the frontiers of territories where one's life or freedom would be threatened on account of one's race, religion, nationality, membership of a particular social group, or political opinion. ${ }^{31}$ As discussed under Refoulement, below, a number of cases of the forcible return of refugees have been reported to HCA this year. Unless asylum procedures are made universally available to foreign nationals, legitimate refugees will continue to be refouled before being able to apply for asylum.

\section{Procedural Safeguards for Detained Refugees}

\section{Domestic safeguards}

Since guesthouses are generally viewed as a form of administrative detention, refugees detained therein are accorded certain procedural rights, though many fewer than criminal detainees. ${ }^{32}$ Article 19 of the Turkish Constitution guarantees that persons deprived of their liberty for whatever reason:

- have the right to a speedy conclusion of their case;

- may apply to a judicial body to challenge the lawfulness of his/her detention; and

- should be released if the detention is found to be unlawful. ${ }^{33}$

These rights are consistent with those articulated in the ECHR and ICCPR. ${ }^{34}$ However, as discussed below and set out under "The Right to Access Asylum Procedures," in practice, refugee detainees have no access to judicial review, or to the legal counsel necessary to carry out an effective proceeding to do so. As a result, they are unable to challenge

(C) Rachel Levitan, Esra Kaytaz and Oktay Durukan, 2009. This open-access work is licensed under a Creative Commons AttributionNonCommercial 4.0 International License, which permits use, reproduction and distribution in any medium for non-commercial purposes, provided the original author(s) are credited and the original publication in Refuge: Canada's Journal on Refugees is cited. 
the legality or length of their detention. This significant lack of domestic procedural safeguards for detainees in guesthouses in Turkey has been clearly articulated by the UN Working Group on Arbitrary Detention. ${ }^{35}$

\section{International safeguards}

In contrast to the minimal protections for administrative detainees in the Turkish Constitution, international guidelines delineate substantially more rights for refugees held in detention. The UN Working Group on Arbitrary Detention (UNWGAD) and the UNHCR Detention Guidelines set forth specific prerequisites for the legal detention of refugees. As an overarching principle, they hold that the illegal deprivation of liberty constitutes "arbitrary detention." 36 The rights articulated in these instruments, which are discussed below, include:

- communication of the reasons for and length of detention; ${ }^{37}$

- the right to judicial review of the reasons for and length of detention; ${ }^{38}$ and

- the right to legal counsel, including the right to contact a lawyer, local UNHCR offices, other agencies, or non-governmental organizations. ${ }^{39}$

Communication of reasons for and length of detention. International guidelines are unambiguous with regard to the right of refugees to be informed of the reasons for their detention and their rights while detained. UNHCR's Detention Guidelines provide that, if detained, asylum seekers: "receive prompt and full communication of any order of detention, together with the reasons for the order, and their rights in connection with the order, in a language and in terms which they understand." 40

Similarly, the UNWGAD holds that: "Notification of the custodial measure must be given in writing, in a language understood by the asylum-seeker or immigrant, stating the grounds for the measure ..." 41

Under international law, authorities are also required to provide information about the length of the detention. ${ }^{42}$

As discussed under grounds for the detention of refugees, none of the interviewees were informed of the reasons for their arrest, the expected length of detention, or their rights in detention. Many faced indifference or aggression from the police when they asked for this information. Similarly, none were given information about the expected length of their detention, leading to feelings of hopelessness and depression.

Judicial review. One of the central rights of detainees, delineated under both international and domestic law, is the right to challenge the lawfulness of one's detention in court. ${ }^{43}$ The UNCHR Detention Guidelines provide that refugees in detention have the right: to have the decision subjected to an automatic review before a judicial or administrative body independent of the detaining authorities. This should be followed by regular periodic reviews of the necessity for the continuation of detention, which the asylumseeker or his representative would have the right to attend. ${ }^{44}$

In a similar vein, the UNWGAD establishes the right to "apply for a remedy to a judicial authority, which shall decide promptly on the lawfulness of the measure and, where appropriate, order the release of the person concerned." 45 Article 19 of the Turkish Constitution also guarantees the right to apply to a judicial body to challenge the lawfulness of one's detention. ${ }^{46}$

As the findings of this report indicate, however, refugees held in guesthouses in Turkey have no recourse to judicial review to challenge the legality or the length of their detention. This is clearly linked to the fact that they also have no substantial access to legal counsel. It also is connected to the fact, as discussed below, that detainees are rarely informed of the status of their asylum applications, which prevents them from being able to determine whether the proceedings are being carried with "due diligence."

The right to legal counsel. Refugees in detention have the right to legal counsel, ${ }^{47}$ and should be notified of this right upon being detained. ${ }^{48}$ International guidelines clearly set out refugees' right to communicate with legal counsel, as well as other agencies and advocates. ${ }^{49}$ The UNHCR Detention Guidelines require that refugees have access to free legal aid. ${ }^{50}$

Moreover, in order for detainees to receive effective legal counselling, they should be provided with adequate time and privacy during the visits from lawyers and advocates. Article 18(3) of The Body of Principles for the Protection of All Persons under Any Form of Detention or Imprisonment, for instance, states that: "The right of a detained or imprisoned person to be visited by and to consult and communicate, without delay or censorship and in full confidentiality, with his legal counsel may not be suspended or restricted save in exceptional circumstances ..."

Although Article 19 of the Turkish Constitution does not explicitly set out the right of administrative detainees to legal counsel, clearly the articulated right to judicial review would not be effective if carried out without the benefit of legal counsel. This is certainly the case for refugees, the vast majority of whom speak no Turkish. Other than an implied right to legal counsel, refugees are not guaranteed the right to access other advocates or agencies.

In practice, as already discussed, foreign nationals in guesthouses are provided only sporadic access to lawyers. Those interested in applying for refugee status are often given access to visiting UNHCR representatives, but this is

(C) Rachel Levitan, Esra Kaytaz and Oktay Durukan, 2009. This open-access work is licensed under a Creative Commons AttributionNonCommercial 4.0 International License, which permits use, reproduction and distribution in any medium for non-commercial purposes, provided the original author(s) are credited and the original publication in Refuge: Canada's Journal on Refugees is cited. 
certainly not the case in all guesthouses in Turkey. Visits by other international agencies, NGOs or advocates are strictly prohibited. Neither lawyers, UNHCR representatives nor any other advocates are provided access to asylum seeker held in airport transit zones.

\section{Length of detention}

International law and guidelines hold that the detention of refugees should be limited, and that any procedures carried out during a refugee's detention be carried out with "due diligence." Lengths of detention deemed lawful vary according to the specifics of each case, but will be found "excessive" if the procedures are carried out without due diligence. ${ }^{51}$ The European Court of Human Rights and the United Nations Human Rights Committee emphasize that expulsion procedures, for instance, be carried out with "due diligence" rather than specifying a maximum length of time for detention. ${ }^{52}$ UNWGAD states that a maximum period of detention "should be set by law and the custody may in no case be unlimited or of excessive length." 53

Turkish regulations are silent on the appropriate length of detention in guesthouses. As a starting point, Turkey's 1983 Directive on Refugee Guesthouses (1983 Directive) emphasizes that a refugee's stay in a guesthouse is "temporary." 54 Pursuant to that directive, refugees can only be kept in detention until they have obtained visas to leave the country or obtained permission from the MOI to reside in a satellite city. ${ }^{55}$

The only reference to a specific time frame to process the asylum applications of detainees is set forth in Section 13 of the 2006 Circular. That provision holds that, pursuant to an expedited procedure, authorities must process the asylum applications of foreign nationals who have been detained for illegal exit or entry within five working days. ${ }^{56}$ In practice, as already discussed, the asylum application process generally takes several months.

\section{Findings Based on Interviews with Detained Refugees}

I was arrested with a Senegalese friend when I was selling bottles of perfume and watches in a bazaar. I was trying to earn the money I needed to go to Kayseri to register with the police there. I had my UNHCR document with me and my Senegalese friend had a passport with him. The police took us to the police station in Cebeci.

In Cebeci, we spent three days without anything to eat. We slept on a foam mattress on the floor. The bed covers were filthy. There wasn't a toilet in the room. We also had to drink water from the bathroom. There was a nice police officer who took us to the bathroom but the other one never listened to us. I started to get sick there. It was very cold. When I was arrested I was feeling dizzy. I asked for medicine but the police refused to give it to me.

Three days after arriving in Cebeci, my Senegalese friend was deported and the police took me to the Zeytinburnu Foreigner's Department. We were given soup with bread twice a day, but I was still hungry afterward. On the weekends, I only got small slices of bread with olives once a day. The room and the water in the bathroom were so cold I couldn't wash myself. The tap water from the bathroom made me feel sick. I slept on the carpet and found some covers. The room was very cold. I couldn't sleep because of the insects on the floor. When we all lay down on the floor to sleep our feet would touch somebody else. It was so crowded that we couldn't turn. Everybody was so tense that when someone touched them when they were asleep they jumped or got upset.

When I was in Zeytinburnu I thought back to the time I was arrested in Mauritania. I was feeling very sick, so I kept to myself. The police wouldn't listen to anyone. I wanted to complain about my kidney and stomach problems, but they just slapped people and made them go away if they complained.

I called ICMC (the International Catholic Migration Commission) from detention. I think they spoke with the police. I was meant to go to Kayseri but the police said that I had to go to Konya with three other Africans. The police said that the men had to each pay $\$ 100$ to cover the transportation to Konya. The police took one of us outside to collect money. In the end, there were collections from the community so we were able to pay the police. When we arrived in Konya, there was nowhere to stay and we had no money.

Now I am very afraid. I have no money because I am afraid to sell watches. I had to come back to Istanbul because there was nowhere for me to stay in Konya. I am scared of the police so I sometimes don't leave the house for a couple of days in a row. I can't afford to see the doctor for the kidney problem I got in Zeytinburnu. ${ }^{57}$

The experience of this Mauritanian refugee in detention is representative of many aspects of the experience of people interviewed for this report. Like many other interviewees, he states that he was kept in substandard conditions, was intimidated by the police, and was unable to get medical attention. He also describes being required to pay an inflated amount for his transfer to a satellite city.

This section discusses the results of surveys conducted with the forty detained or formerly detained refugees interviewed for this report. The findings of the surveys are discussed in the context of procedural rights (including the right to access asylum procedures, procedural safeguards, and the length of detention), a range of conditions in detention, and the treatment of minor refugees in detention.

(C) Rachel Levitan, Esra Kaytaz and Oktay Durukan, 2009. This open-access work is licensed under a Creative Commons AttributionNonCommercial 4.0 International License, which permits use, reproduction and distribution in any medium for non-commercial purposes, provided the original author(s) are credited and the original publication in Refuge: Canada's Journal on Refugees is cited. 
Access to Asylum Procedures

The interviewees held in guesthouses reported significant barriers to accessing the asylum procedure in Turkey. Primarily, the reported reasons for this included a lack of information about asylum procedures and refusal by police to take asylum applications.

Notably, the interviewees held in airport transit zones reported that they were completely barred from applying for asylum. As discussed below, the failure by refugees to access the asylum procedure has led to numerous instances of refoulement-the return to the frontiers of territories where one's life or freedom would be threatened.

Out of the forty interviewees, eighteen had not applied for asylum when they were arrested. Of these, eleven reported applying for asylum in detention. HCA counselled nine of eleven interviewees regarding their asylum applications when they were in detention. These refugees all reported extreme difficulty in submitting their asylum applications either in writing or orally. Three reported that the police took their applications, while the other six reported being released with deportation orders despite numerous attempts to submit asylum applications.

Of the three interviewees whose asylum applications were received by police:

- one interviewee was released to her satellite city after four months of detention with her three minor children;

- another stated that he was detained for six months before he applied for asylum due to a lack of information about the process, and remained in detention for another five months after he applied; and

- a third interviewee reported that his attempts to submit both written and oral asylum applications were denied by the police for four months; as of November 2007, seven months after his application was finally received, he is still in detention.

Of the six interviewees released with deportation orders:

- two were told by the police in the Kumkapi guesthouse that the Turkish state does not take asylum applications and were referred to the UNHCR. When they contacted UNHCR, they were informed that the UNHCR could only take their asylum applications if they submitted an asylum petition to the police. They alleged that the police never accepted their petitions for asylum. They were later released with deportation orders.

- four detained in the Kirklareli Gazi Osman Pasa guesthouses stated that, prior to being released with deportation orders, police forced them to write a letter withdrawing their asylum applications from the Turkish state and stating their intention never to seek asylum again. The interviewees claimed that the police had intimidated them by alleging that anyone who applies for asylum will be detained for at least two years without receiving any assistance.

\section{Lack of information}

The interviewees who made their asylum applications in detention generally claimed that they were not counselled on the asylum procedure in Turkey. Even after submitting their asylum applications, the police did not offer any advice or information on the asylum procedure. Interviewees also reported being faced with hostile or indifferent attitudes from the police when they inquired about placing an asylum application or requested information about the status of their case. The lack of interpreters was identified by interviewees as a further impediment to their ability both to obtain relevant information and generally access the asylum system.

Interviewees who had registered with the UNHCR said that they were unaware of the requirement to present oneself at the designated satellite city to register with the police. The interviewees held the incorrect assumption that once they had been issued a UNHCR Asylum Seeker Certificate, they could not be deported. ${ }^{58}$ In recent months, however, an increased awareness of the obligation to reside in satellite cities has been noted among refugees in detention.

Although the MOI has printed information brochures about the domestic asylum procedures in a range of refugee languages, these brochures were not reported to be distributed to refugees in detention.

\section{Police refusal to take asylum applications}

\begin{abstract}
I had an interview with the police officer. I told him that my passport was not a fake passport. The interpreter wasn't good. The officer told me that I must pay to get a ticket to get home. I said that I don't have money to get a ticket and I cannot return home because I am a refugee. He told me to call UNHCR because they can't do anything for me. But UNHCR told me I should tell the police. I told the police many times that I wanted to give my petition to claim asylum but the police said no. In the end, I was released with an order of deportation so the police never took my asylum application. ${ }^{59}$
\end{abstract}

Like this refugee, interviewees often reported that the police refused to accept their written asylum applications. In some instances, interviewees said that police provided misleading or false information about the asylum procedures. Despite interventions by HCA and the UNHCR, many refugees held in guesthouses across Turkey, including in Ankara, Edirne, and Hatay, have unsuccessfully attempted to apply for asylum with the police. 
In the summer of 2007, for instance, fifty-one Afghan refugees were reported to have been detained for two months in a makeshift detention facility on the Aegean Coast near Ayvalik. They claimed that police refused to process their asylum applications. In particular, they alleged that when they submitted written asylum applications, the police claimed that they were going to fax the asylum petitions to MOI. Instead, the following day, the Afghan men were distributed paperwork from the Afghan Consulate to process their deportation from Turkey. The police, they claim, ordered them to sign the letters. Upon their refusal, the detainees received a visit from a local state official who told them to sign the papers. After a day and a half of refusing to sign, the detainees reported that the police beat some of them. They also reported being denied food and water for twenty-four hours. Despite efforts by HCA and Amnesty International-Turkey to intervene to prevent the deportation, contact was lost with these detainees.

\section{Airport transit zones}

Based on HCA's attempts to assist refugees held in detention facilities in airports in Turkey, it is apparent that MOI will not accept asylum applications from transit zones. As discussed below, MOI also refuses to allow lawyers, UNHCR representatives, or other advocates to visit these areas to counsel detainees. HCA receives several calls a year from detention facilities in airports, in particular Istanbul Ataturk Airport. All detainees report being denied their right to apply for asylum and are immediately deported.

In December 2006, for instance, a Nigerian refugee traveling with false documentation from Nigeria to the United Kingdom was detained in the Istanbul Ataturk Airport during a stop over. He informed the police both orally and in writing that he wanted to apply for asylum on the basis of his membership in a political group. If returned to Nigeria, he said, he would face torture and death. The police refused to accept his application for asylum. Despite attempts by HCA to stop his deportation, and although an application was submitted to the European Court of Human Rights and contact was made with the UNHCR, he was deported to Nigeria. For more details about his case, please see Appendix 2.

\section{Refoulement}

When in detention, refugees appear to incur a greater risk of deportation than when residing outside detention facilities. The instances of refoulement ${ }^{60}$ reported to HCA in 2007 include:

- two Iranians and three Sri Lankans deported from the Istanbul Ataturk Airport without being allowed to apply for asylum;
- a recognized Iranian refugee deported while awaiting resettlement after being detained for failing to register with Turkish police;

- an Iranian refugee deported from the Aliens' Guesthouse in Ankara despite having an open file with UNHCR;

- as discussed above, fifty-one Afghan refugees threatened with deportation from Ayvalık after police refused to accept their asylum applications and both verbally and physically abused them (the whereabouts of these refugees is unknown and the likelihood is that they have been deported); and

- three Baha'i Iranian refugees deported despite verbally communicating their wish to claim asylum and instructions from UNHCR that the police accept their applications (they were part of a group of 60 Iranians which may also have included other refugees);

These examples point to consistent disregard by Turkish authorities of the right of detainees to access the domestic asylum process. It is hoped that the European Court of Human Rights order of July 20, 2007 to stay the deportation of an Afghan refugee will act as a catalyst for the Turkish authorities to act according to its commitment to the principle of non-refoulement. In the aforementioned case, although the refugee had submitted his asylum application to the UNHCR and MOI, MOI initiated deportation proceedings. At the initiation of Amnesty International-Turkey, his legal representatives successfully applied to the European Court of Human Rights to prevent his deportation.

\section{Procedural Safeguards}

Despite procedural rights guaranteed by both international standards and domestic legislation, interviewees reported being denied:

- communication of the reasons for and length of for detention; 61

- the right to judicial review of the reasons for and/or length of detention; ${ }^{62}$ and

- the right to legal counsel, including the right to contact a lawyer, local UNHCR offices, other agencies or non-governmental organizations. ${ }^{63}$

\section{Communication of the reasons for and length of detention}

We always asked why we were arrested. We knew that we shouldn't be there more than two weeks or a month. So we asked why. The police said we were arrested because an African shot a gun in the air and killed a woman and they did not know which one of us had done it. Some of the policemen spoke English. Most said that they knew nothing, they were there just to guard us. ${ }^{64}$ 
International guidelines provide that, if detained, refugees should receive prompt and full communication of the order of detention, together with the reasons for the order, and their rights in connection with the order, in a language and in terms which they understand. ${ }^{65}$ Authorities are also required to inform detainees of the length of the detention. ${ }^{66}$

None of the interviewees reported being informed of the reasons for their arrest or their rights in detention. Generally, when the interviewees asked the police for the reason for their arrest and detention, they stated that the police responded aggressively or were indifferent. Interviewees claimed that they were not provided with any information regarding the status of their application for asylum throughout their detention. Nor were they brought to court to be informed that they had been found in violation of the Passport Law for attempting to enter or exit the country illegally. ${ }^{67}$

Similarly, according to the detainees surveyed, police rarely provided information about the length of time that they were to be detained. As discussed below, not knowing when they might be released often leads to feelings of hopelessness and depression among the detainees.

\section{Judicial review}

Both domestic and international standards guarantee refugees the right to apply to a judicial body to challenge the lawfulness and length of their detention. ${ }^{68}$

In practice, no system of judicial review exists in Turkey for detainees in guesthouses, and as a result, refugees have no means to challenge the legality or length of their detention.

\section{The right to legal counsel}

As discussed under "Procedural Safeguards for Detained Refugees," refugees in detention have the right to retain legal counsel ${ }^{69}$ and to communicate with other agencies and advocates, ${ }^{70}$ and should be notified of this right upon being detained. ${ }^{71}$ They also should be provided with adequate time and privacy during visits from lawyers and advocates.

In Turkey, detained refugees' access to advocates appears to fall well below international standards. Interviewees reported having only very sporadic access to lawyers. They also said that they were unable to receive visits from any NGO advocates. Most troubling is that refugees held in airport transit zones in Turkey reported having no access at all to lawyers, the UNHCR or other agencies, or advocates. This is linked to the fact that they are prevented from accessing asylum procedures altogether.

\section{Length of Detention}

International law and guidelines hold that the detention of refugees should be limited. If procedures implemented during a refugee's detention are not carried out with "due diligence," 72 the detention will be considered "excessive."73 The 1983 Directive provides that a refugee's stay in a guesthouse should be "temporary." 74

As a fundamental matter, since interviewees alleged that they are not provided consistent access to legal counsel, and are not informed of the status of their asylum applications, they are unable to determine whether their detention is being carried out with "due diligence." As a result, they cannot challenge the length of detention as "excessive," and as discussed above, are effectively denied the right to judicial review.

Based on information provided by the interviewees, the duration of detention periods increased over the course of 2007. This is particularly the case for refugees who first apply for asylum when in detention, who tend to be detained for at least six months. The interviewees who were detained between three months and one year applied for asylum in detention either at the end of 2006 or at the beginning of 2007. Interviewees who were found to be in violation of their residence requirements, but who had registered with UNHCR, were detained for longer periods in 2007 than in 2006, when most refugees were detained for, on average, between a month and three months.

Of those interviewed, detention periods ranged from less than a week to more than a year. The largest number (twenty-three) were detained for between one week and one month. Seven were detained between one and three months; nine between three and six months; two between six months and a year; and one for more than a year. Only four were detained for less than a week.

Interviewees reported that their detention was often prolonged while they collected the money necessary to travel, along with a police officer, to their satellite cities. Detainees reported paying varying, apparently arbitrary amounts for this transportation. They typically reported being charged from $\$ 100$ to $\$ 150$ per person, which is significantly higher than the actual cost of travel to any satellite city, even factoring in the cost of an accompanying police officer. Since the interviewees were never provided with official receipts upon payment of the travel fee, they were uncertain how this transaction was administered. No official regulation concerning this required fee has come to the attention of HCA.

In November 2006, for example, an interviewee detained in the Zeytinburnu guesthouse was taken out of the guesthouse, accompanied by two police officers, reportedly to find $\$ 300$ to cover the cost of transportation to a satellite city for himself and two friends. He was brought to the HCA office handcuffed asking for money. Members of his community eventually provided the full amount required. The interviewee later learned that two refugee women, 
who accompanied him on the bus to the same satellite city, were only charged 50 Turkish lira (YTL) each for the transportation.

\section{Addendum}

In September 2009, the European Court of Human Rights issued a watershed decision holding that Turkey's system for detaining foreign nationals in detention centres (called "foreigners' guesthouses" at the time) had no legal basis, and that as a result, the applicants had been arbitrarily detained in violation of Article 5 of the European Convention on Human Rights (Abdolkhani and Karimnia v. Turkey, Appl. No. 30471/08, Council of Europe: European Court of Human Rights, 22 September 2009). Some seven months later, the Court also ruled that conditions in two Turkish detention facilities amounted to inhuman or degrading treatment or punishment in violation of Article 3 of the Convention (Tehrani and Others v. Turkey, Appl. Nos. 32940/08, 41626/08, 43616/08, Council of Europe: European Court of Human Rights, 13 April 2010; Charahili v. Turkey, Appl. No. 46605/07, Council of Europe: European Court of Human Rights, 13 April 2010).

Since then, Turkish authorities have redrafted the domestic provision relating to the administrative detention of foreign nationals-Article 23 of the Law on Sojourn and Travel of Aliens in Turkey (Law No. 5683) - but the content of the new article has not been made public. In May 2010, a platform of domestic human rights NGOs (the Turkey Coordination for Refugee Rights) requested a copy of the draft article to provide feedback, and at the time of publication of this paper, was awaiting a response from the government. As part of a related initiative, Turkey issued a directive in March 2010, changing the name of "foreigners' guesthouses" to "removal centres." The directive calls for the construction of many new removal centres across the country, and sets out minimum standards for facility conditions, including access to sufficient food, adequate health care, bedding, sunlight, and outdoor recreation. At the time of publication of this paper, it was too early to tell whether any of these conditions had been implemented. Thus, while Turkish authorities have recently taken steps to respond to the recent ECtHR decisions, they have significant work to do to ensure that asylum seekers and refugees are not arbitrarily detained and that best practices are implemented to protect their basic human rights while their liberty is restricted.

\section{Notes}

1. The practice of returning a person to a country where his or her life or liberty would be threatened.

2. Under Rule 39 of the Rules of Court.
3. Convention relating to the Status of Refugees, 28 July 1951, 189 U.N.T.S. 150 (Refugee Convention) p. 37, Article 1b(1), online: UNHCR Refworld, <http://www.unhcr.org/cgi-bin/ texis/vtx/refworld/rwmain?docid=3b01b964>.

4. Turkey interprets the term "European" to include nationals of Council of Europe member states.

5. According to UNHCR Branch Office Ankara figures, as of 31 December 2009, there were 16,337 refugees and asylum seekers registered with UNHCR Turkey, 7,834 of whom applied in 2009. The leading four countries of origin were Iraq (42 per cent), Iran ( 26 per cent), Afghanistan (18 per cent), and Somalia (7 per cent).

6. Refugee Convention, Article 35.

7. Regulation on the Procedures and the Principles Related to Mass Influx and Foreigners Arriving in Turkey either as Individuals or in Groups Wishing to Seek Asylum from a Third Country, 1994, Article 3.

8. The number of these cities is in flux.

9. Regulation on the Procedures and the Principles Related to Mass Influx and Foreigners Arriving in Turkey either as Individuals or in Groups Wishing to Seek Asylum from a Third Country, 1994, Article 4.

10. See 2006 Circular, Section 2, on Duties of Application Authorities.

11. See 2006 Circular, Section 19 on Facilities to be Provided for Asylum Applicants and Beneficiaries.

12. See Turkish National Action Plan for the Adoption of the EU Acquis in the Field of Asylum and Migration (NAP), Section 4.13 on Lifting of the Geographical Limitation.

13. UN High Commissioner for Refugees, Revised Guidelines on Applicable Criteria and Standards relating to the Detention of Asylum-Seekers (UNHCR Detention Guidelines), 26 February 1999, Guideline 1.

14. See UN Working Group on Arbitrary Detention, Implementation of General Assembly Resolution 60/251 of 15 March 2006, Entitled "Human Rights Council," Addendum, Mission to Turkey, A/HRC/4/40/Add.5, 7 February 2007, paragraphs 86-90.

15. The European Committee for the Prevention of Torture and Inhuman or Degrading Treatment or Punishment Standards, Extract from the $7^{\text {th }}$ General Report [CPT/ Inf (97) 10], "Substantive" sections of the CPT's General Reports, CPT/Inf/E (2002) 1-Rev. 2003, English.

16. EU Commission Proposal for a Council Directive Laying Down Minimum Standards on Reception of Applicants for Asylum in Member States, COM (2001) 181 final.

17. See e.g. $<\mathrm{http}: / /$ www.iem.gov.tr $/ \mathrm{iem} /$ ? $\mathrm{m}=1 \& \mathrm{~s}=31 \& \mathrm{idno}=91>$.

18. E.g. JRS-EUROPE (2005) Detention in Europe: Administrative Detention of Asylum Seekers and Irregular Migrants; FRONTIERS (2006) Legality vs. Legitimacy: Detention of Refugees and asylum seekers in Lebanon.

19. Turkish Constitution, Article 19; see also UN Working Group on Arbitrary Detention, Implementation of General Assembly Resolution 60/251 of 15 March 2006, entitled 
"Human Rights Council," Addendum, Mission to Turkey, A/HRC/4/40/Add.5, 7 February 2007, paragraphs 86-90.

20. Passport Law, Article 34.

21. Passport Law, Article 34.

22. The Law on the Sojourn and Movement of Aliens, Article 25.

23. The Law on Residence of Foreign Citizens, Article 23.

24. UNWorking Groupon ArbitraryDetention, Implementation of General Assembly Resolution 60/251 of 15 March 2006, entitled "Human Rights Council," Addendum, Mission to Turkey, A/HRC/4/40/Add.5, 7 February 2007, paragraphs $86-90$.

25. UNHCR Detention Guidelines; see also UNHCR Comments on the 2005 Immigration and Nationality Bill, October 2005, London, UK ('UNHCR's view is that the detention of asylum seekers is inherently undesirable, and that there must be a presumption against its use"); online: $<$ http://www.unhcr.org.uk/legal/positions/UNHCR\%20 Comments/Comments2005IANbilldetention.htm>.

26. UNHCR Detention Guidelines, Introduction (para. 3).

27. EXCOM Conclusion No. 44 (XXXVII); UNHCR Detention Guidelines, Guideline 3(iii).

28. 1994 Asylum Regulation, Article 4.

29. Ibid.

30. UNHCR Detention Guidelines, Guideline 5.

31. Refugee Convention, Article 33; 1984 United Nations General Assembly, Convention against Torture and Other Cruel, Inhuman or Degrading Treatment or Punishment: resolution/ adopted by General Assembly (CAT), 10 December 1984. A/RES/39/46, Article 3, online: UNHCR Refworld, <http://www.unhcr.org/cgi-bin/texis/vtx/refworld/rwmain?docid=3b00f2224>; see also, Chahal $v$. UK (app 22414/93), Judgment of November 1996 (1997); Gorki Tapia Paez v. Sweden Communication 83/1997, CAT/ $\mathrm{C} / 20 / \mathrm{D} / 83 / 97$

32. Those charged with criminal offences are guaranteed the right to: be notified promptly for the reasons for the arrest and the charges brought; be brought before a court within forty-eight hours of arrest; have next of kin informed immediately of the arrest or detention; be brought to trial in a reasonable period of time; and be compensated if any of these provisions are violated. See Turkish Constitution, Article 19. Refugees who are arrested for criminal violations of the Passport Law, by, for instance, entering Turkey without documentation, are entitled to these rights. Lawyers who have worked in collaboration with HCA state that in practice, refugees, unless charged with a violation of the Turkish Criminal Code, are rarely criminally charged, or accorded the procedural rights of criminal detainees.

33. Ibid.

34. Council of Europe, European Convention for the Protection of Human Rights and Fundamental Freedoms (ECHR), 4 Nov 1950, ETS 5, online: UNHCR Refworld, <http:// www.unhcr.org/cgi-bin/texis/vtx/refworld/rwmain? docid=3ae6b3b04>, Article 5(4), provides: "Everyone who is deprived of his liberty by arrest or detention shall be entitled to take proceedings by which the lawfulness of his detention shall be decided speedily by a court and his release ordered if the detention is not lawful"; see International Covenant on Civil and Political Rights (ICCPR), 19 December 1966, 999 U.N.T.S. 171, Article 9(4), UNHCR Refworld, online: <http://www.unhcr.org/ cgi-bin/texis/vtx/refworld/rwmain?docid=3ae6b3aa0 $>$.

35. UNWorkingGroupon ArbitraryDetention,Implementation of General Assembly Resolution 60/251 of 15 March 2006 entitled "Human Rights Council," Addendum, Mission to Turkey, A/HRC/4/40/Add.5, 7 February 2007, paragraphs 86-90.

36. UN Working Group on Arbitrary Detention (UNWGAD), Civil and Political Rights, Including Questions of Torture and Detention Report, E/CN.4/2000/4, 28 December 1999, passim.

37. UNHCR Detention Guidelines, Guideline 5(i); UNWGAD, Annex 2, Principle 8.

38. UNHCR Detention Guidelines, Guideline 5 (iii); UNWGAD, Annex 2, Principle 8.

39. UNHCR Detention Guidelines, Article 5(ii), UNWGAD, Annex 2, Principle 2.

40. UNHCR Detention Guidelines, Guideline 5(ii).

41. UNWGAD, Annex 2, Principle 8.

42. E.g. ECHR, Article 5.

43. Turkish Constitution, Article 19; ICCPR, Article 9(4); ECHR, Article 5(4).

44. UNHCR Detention Guidelines, Guideline 5(iii).

45. UNWGAD, Annex 2, Principle 8.

46. Turkish Constitution, Article 19.

47. UN General Assembly, Body of Principles for the Protection of All Persons under Any Form of Detention or Imprisonment, Principle 17(1), 9 December 1988, online: UNHCR Refworld, <http://www.unhcr.org/cgi-bin/texis/ vtx/refworld/rwmain?docid=3ae6b38b34>.

48. UNHCR Detention Guidelines, Guideline 5(ii), UN, Body of Principles for the Protection of All Persons under Any Form of Detention or Imprisonment, Principle 17(2).

49. UNHCR Detention Guidelines, Guideline 5(v); UNWGAD, Annex 2, Principle 2; UN, Body of Principles for the Protection of All Persons under Any Form of Detention or Imprisonment, Principles 16 \& 18.

50. UNHCR Detention Guidelines, Guideline 5(ii); UNWGAD, Annex 2, Principle 10.

51. UN Doc. CCPR/C/79/Add.70 (1996) (holding that the Swiss practice of three-month-long detention of foreign nationals for the preparation of temporary residence permit and waiting times ranging from nine months to a year for the preparation for expulsion as excessive and discriminatory).

52. Chahal v. UK (app 22414/93), Judgment of n/d November 1996; Kolompar v. Belgium, Judgment of 24 September 1992.

53. UNWGAD, Annex 2, Principle 7. 
54. 1983 Directive, Article 16.

55. Ibid.

56. While HCA does not support the use of an expedited process for the determination of asylum applications, this provision is included to illustrate the fact that the Ministry of Interior, in issuing this regulation, expressed an intention to detain refugees for a limited period of time.

57. Mauritanian refugee, December 2006.

58. The Asylum Seeker Certificate is issued by the UNHCR after registration with that agency is complete, and includes the refugee applicant's name, country of origin, and the satellite city to which he or she has been assigned.

59. Congolese refugee held in the Kumkapı guesthouse.

60. Article 33 of the CAT defines refoulement as return to the frontiers of territories where one's life or freedom would be threatened on account of one's race, religion, nationality, membership of a particular social group, or political opinion.

61. UNHCR Detention Guidelines, Guideline 5(i); UNWGAD, Annex 2, Principle 8.

62. UNHCR Detention Guidelines, Guideline 5 (iii); UNWGAD, Annex 2, Principle 8.

63. UNHCR Detention Guidelines, Article 5(ii); UNWGAD, Annex 2, Principle 2.

64. Guinean refugee who was detained in the Zeytinburnu guesthouse. He was arrested in a series of house raids initiated following the alleged shooting of a woman in the Tarlabası district of Istanbul, August 2006. Interviewees reported that about three hundred African nationals were arrested during these house raids.

65. UNHCR Detention Guidelines, Guideline 5(i); UNWGAD, Annex 2, Principle 8.

66. E.g. ECHR, Article 5.

67. As discussed in the first section, refugees who enter or exit Turkey without documentation may face criminal charges for the violation of the Passport Law. Lawyers working in the field note that the Prosecutor often reviews the cases of foreigners found in violation of the Passport Law in their absence.

68. Turkish Constitution, Article 19; UNHCR Detention Guidelines, Guideline 5(iii); UNWGAD, Annex 2, Principle 8.

69. UN, Body of Principles for the Protection of All Persons under Any Form of Detention or Imprisonment, Principle 17; UNHCR Detention Guidelines, Guideline 5(ii).

70. UNWGAD, Annex 2, Principle 10.

71. UNHCR Detention Guidelines, Guideline 5(ii).

72. Chahal v. UK (App. 22414/93), Judgment of $\mathrm{n} / \mathrm{d}$ November 1996; Kolompar v. Belgium, Judgment of 24 September 1992.

73. UNWGAD, Annex 2, Principle 7.

74. 1983 Directive, Article 16.

Esra Kaytaz received a BA in Archaeology and Anthropology and an MPhil in Development Studies from the University of Oxford. Prior to taking up her current position as Research Officer at the Global Migration Governance Project (University of Oxford), she spent two years working with the Helsinki Citizens' Assembly Turkey's Refugee Advocacy and Support Program coordinating its detention program and as a legal advisor.

Rachel Levitan received a BA from McGill University and an LLB from the University of British Columbia. She is cofounder and legal director of Helsinki Citizens' Assembly Turkey's Refugee Advocacy and Support Program.

Oktay Durukan received BAs in Political Science / International Relations and Sociology from Bogazici University and is pursuing an LLM at Istanbul Bilgi University. He is responsible for advocacy and training activities at Helsinki Citizens' Assembly Turkey's Refugee Advocacy and Support Program. 